\title{
Big and Little Forms of Osteoclast Activating Factor
}

\author{
Gregory R. MUNDY and LAWRENCE G. RAISZ with the technical assistance of \\ James L. Shapiro, Janet G. Bandelin, and Robert J. TURCotTe \\ From the Division of Endocrinology and Metabolism, Department of Medicine, University of \\ Connecticut School of Medicine, Farmington, Connecticut 06032
}

A B S T RACT We have further characterized osteoclast activating factor (OAF) using a bioassay for bone resorption which utilizes the release of previously incorporated ${ }^{45} \mathrm{Ca}$ from fetal rat long bones in organ culture. When supernatant media from activated leukocyte cultures were concentrated on Amicon PM10 membranes (assigned molecular weight cutoff 10,000 daltons) and chromatographed on Sephadex G-50 columns, the bone-resorbing activity eluted between the molecular weight markers chymotrypsinogen (25,000 daltons) and cytochrome $c$ (12,500 daltons). This peak of biological activity has been called big OAF. When filtrates from the PM10 membranes were concentrated on Amicon UM2 membranes (assigned molecular weight cutoff 1,000 daltons) and chromatographed on Sephadex G-50 columns, some of the biological activity eluted between the molecular weight markers chymotrypsinogen and cytochrome $c$ (big OAF), but there was a separate peak of biological activity which eluted with $\left[{ }^{3} \mathrm{H}\right]$ proline (140 daltons). This second peak has been called little OAF. Little OAF was eluted from Bio-Gel P6 columns between the molecular weight markers calcitonin (approximately 3,500 daltons) and vitamin $B_{12}$ (1,330 daltons), but was retained by Spectrapor dialysis tubing (nominal molecular weight cutoff 3,500 daltons). Big OAF was converted to little OAF by equilibration in $1 \mathrm{M} \mathrm{NaCl}$ or $2 \mathrm{M}$ urea. Little OAF was self-associated back to big OAF by equilibration in buffers of low ionic strength (Tris- $\mathrm{HCl} 10-50 \mathrm{mM}$ ). Little OAF was extracted into the organic phase in ethyl acetate after acidification of the sample to $\mathrm{pH}$ 3.5. The biological activity remained in the aqueous phase after ethyl acetate extraction at $\mathrm{pH}$ 7.5-8.4. Little OAF has been purified more than 6,000-fold compared with the original material so that bone-resorbing activity is maximal in a sample with a protein concentration of $80 \mathrm{ng} / \mathrm{ml}$.

Dr. Mundy is supported by Faculty Research Award FRA148 from the American Cancer Society.

Received for publication 11 October 1976 and in revised form 17 March 1977.

\section{INTRODUCTION}

When peripheral blood leukocytes are activated by nonspecific mitogens such as phytohemagglutinin (PHA $)^{1}$ or by antigens to which they have been previously exposed, a potent bone-resorbing factor is secreted into the supernatant medium (2-5). We have called this bone-resorbing factor osteoclast activating factor (OAF) and have distinguished it from other humoral mediators of bone resorption such as parathyroid hormone (PTH), active vitamin D metabolites, and prostaglandins by its chemical and biological characteristics (5). Partial purification of OAF by column chromatography and ultrafiltration yields a macromolecular material which elutes from Sephadex G-100 columns between the molecular weight markers chymotrypsinogen (25,000 daltons) and ribonuclease A (13,700 daltons) (3). Bone-resorbing factors with similar characteristics are secreted by cultured neoplastic cells derived from patients with myeloma and other hematologic neoplasms associated with hypercalcemia and destructive bone lesions (6-7).

In this study we have shown that two distinct peaks of bone-resorbing activity can be found in activated leukocyte culture supernates. The larger peak of activity corresponds to that previously described (3). The smaller peak can be obtained from the larger under conditions favoring the dissociation of electrostatic bonds and then self-associated back to a larger form in buffers of low ionic strength.

\section{METHODS}

Leukocyte cultures. The leukocytes used in these experiments were obtained from the unused fractions of plateletpheresis donations at the Connecticut Red Cross, Farmington, Conn. The leukocytes which contaminated a platelet collection were separated by centrifugation in the plateletphoresis apparatus to yield blood which was enriched with

${ }^{1}$ Abbreviations used in this paper: BGJ, chemically defined medium developed by Biggers et al. (1); OAF, osteoclast activating factor; PHA, phytohemagglutinin; PTH, parathyroid hormone. 
leukocytes. $5 \mathrm{ml}$ of $6 \%$ dextran was added to $10-15 \mathrm{ml}$ of the cell-rich plasma which contained 2-5 $\times 10^{9}$ leukocytes, of which $<5 \%$ were neutrophils. The erythrocytes were allowed to sediment by gravity. The buffy coat was separated from the erythrocytes, and the leukocytes were counted in a Neubauer counting chamber. The leukocytes were diluted in fresh BGJ medium (chemically defined medium developed by Biggers et al. [1]) without added proteins (8) to a concentration of $1-2 \times 10^{6} \mathrm{cells} / \mathrm{ml}$. The method of cell culture was essentially similar to that described before (4), except that the cells were cultured in $1,000-3,000-\mathrm{ml}$ Ehrlenmyer flasks, with $500 \mathrm{ml}$ of culture medium in each flask. The duration of culture was from 18 to $24 \mathrm{~h}$ in an atmosphere of $5 \% \mathrm{CO}_{2}$ in air at $37^{\circ} \mathrm{C}$. The cells were stimulated to produce OAF by $1 \%$ PHA-M, (Grand Island Biological Co., Grand Island, N. Y.). At the end of culture, the supernatant media was decanted and filtered to remove the cells before further study. This medium was then stored at $-20^{\circ} \mathrm{C}$. The supernatant media from these cultures contained amounts of bone-resorbing activity per cell comparable to that produced by the leukocytes cultured under the conditions that we have described before $(2-5)$.

Bioassay for bone resorption. The bioassay used for assessing bone resorption has been described before in detail $(4,8,9)$. In brief, pregnant rats at the 18th day of gestation were injected with $0.4 \mathrm{mCi}$ of ${ }^{45} \mathrm{Ca}$. The following day the rats were sacrificed, and the mineralized shafts of the fetal radius and ulna were dissected free from soft tissue. These bones were precultured for $24 \mathrm{~h}$ in chemically defined BGJ medium (Grand Island Biological Co.) to allow for exchange of loosely-complexed ${ }^{45} \mathrm{Ca}$ with stable calcium in the medium (8). The bones were then cultured either in the test media to be bioassayed or in the corresponding control medium. Bone resorption was quantitated as the percent of total radioactivity released into the medium during the period of culture or as the ratio of ${ }^{45} \mathrm{Ca}$ release into the medium from the test bones compared with the control bones. The results are expressed as means and standard errors for four bone cultures. Statistical differences were analyzed using Student's $t$ test.

Ultrafiltration and diafiltration. Supernatant media prepared in bulk from activated leukocyte cultures were concentrated 20- to 100-fold using Amicon ultrafiltration membranes PM10 and UM2 (Amicon Corp., Scientific Sys. Div., Lexington, Mass.). Diafiltration (ultrafiltration with continuous replacement of the filtered volume with fresh buffer) was performed with 5-10 vol of the indicated buffer. All ultrafiltration steps were performed at $4^{\circ} \mathrm{C}$.

Column chromatography. Column chromatography was performed on concentrated activated leukocyte culture supernates at $4^{\circ} \mathrm{C}$. Columns of Sephadex G-100, fine; Sephadex G-50, fine; Sephadex G-25, superfine (Pharmacia Fine Chemicals, Div. of Pharmacia, Inc., Piscataway, N. J.); and Bio-Gel P6, 100-200 mesh (Bio-Rad Laboratories, Richmond, Calif.) were employed. Biological activity was eluted in the buffer indicated, and where phosphate-buffered saline was used, the phosphate concentration was readjusted to $1 \mathrm{mM}$ by dilution or dialysis before assay.

Extraction in ethyl acetate. Solutions obtained from activated leukocyte cultures or from column eluants were adjusted to the indicated $\mathrm{pH}$ and extracted twice in ethyl acetate. Equal volumes of aqueous buffer and ethyl acetate were used for each extraction. The organic phase was dried under nitrogen and redissolved in BGJ medium before assay at the appropriate dilution.

Dialysis. The dialysis membrane used was Spectrapor no. 3 boiled in water (Spectrum Medical Industries, Inc., Los Angeles, Calif.), which has an assigned molecular weight

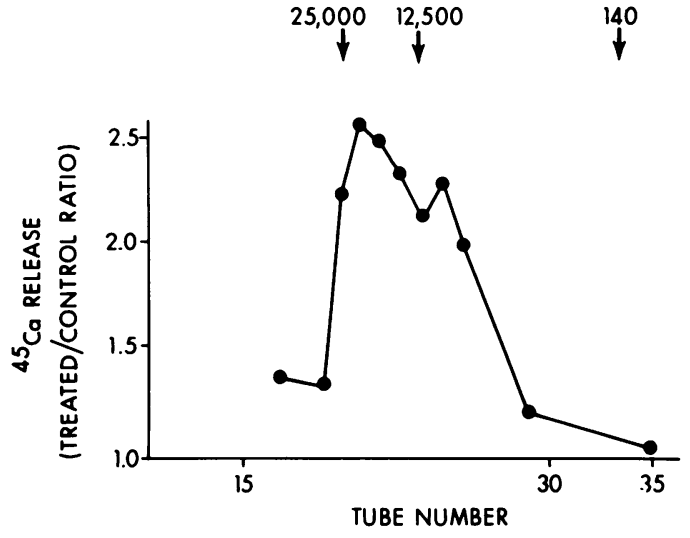

FIGURE 1 Sephadex G-50 chromatography (eluant Tris$\mathrm{HCl}$, ionic strength $50 \mathrm{mM}, \mathrm{pH} \mathrm{7.6)}$ of Amicon PM10 retentate of $\mathrm{PHA}$-activated leukocyte culture supernate which shows elution profile for big OAF. Column markers are chymotrypsinogen (25,000 daltons), cytochrome $c(12,500$ daltons), and $\left[{ }^{3} \mathrm{H}\right]$ proline (140 daltons).

cutoff of 3,500 daltons. Dialysis was performed against 100 vol of fresh BGJ medium before assay.

Enzyme digestion. Concentrated samples (20-fold) of big OAF and little OAF were incubated separately with the enzymes papain $(240 \mu \mathrm{g} / \mathrm{ml})$ and trypsin $(400 \mu \mathrm{g} / \mathrm{ml})$ for $1 \mathrm{~h}$ at $37^{\circ} \mathrm{C}$ in straight $\mathrm{BGJ}$ medium. The mixtures were then diluted 20-fold in fresh BGJ medium containing bovine serum albumin $(4 \mathrm{mg} / \mathrm{ml})$ before assay. Control media incubated with the proteolytic enzymes were also tested for their effects on bone resorption.

Assay for prostaglandin-like activity. Purified little OAF samples prepared by salt dissociation of big OAF, Bio-Gel P6 column chromatography, and ethyl acetate extraction were assayed for prostaglandin-like activity using a sensitive bioassay which detects all known biologically active prostaglandin compounds in low doses (10). This assay was kindly performed by Dr. Hannsjoerg W. Seyberth of Vanderbilt University. Aliquots from the same samples were assayed for bone-resorbing activity.

\section{RESULTS}

Demonstration of little OAF. When concentrated leukocyte culture supernates were chromatographed on Sephadex G-50 columns after concentration on an Amicon PM10 membrane, most of the bone resorbing activity eluted between chymotrypsinogen and cytochrome $c$ (Fig. 1). The apparent shoulder in this chromatogram was not regularly observed and is within the limits of error of the assay. The major peak is similar to that reported previously (3). However, when the filtrate from the PM10 membrane was in turn concentrated on a UM2 membrane (assigned molecular weight cutoff 1,000 daltons) and chromatographed on a Sephadex G-50 column, the bone-resorbing activity eluted in two peaks. One of these peaks coincided with the previously described peak and eluted from the column with chymotrypsinogen and ribonuclease A. This peak is henceforth called big OAF. There

Big and Little Osteoclast Activating Factor 


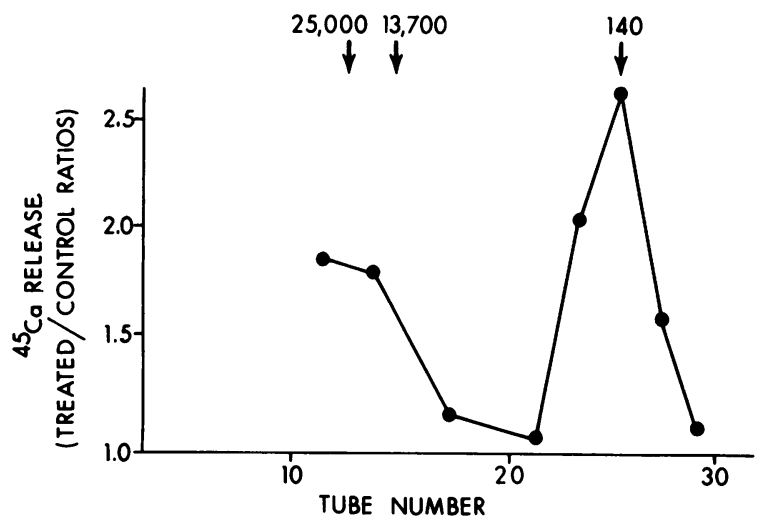

FIGURE 2 Sephadex G-50 chromatography (eluant phosphate-buffered saline, ionic strength $150 \mathrm{mM}, \mathrm{pH} \mathrm{7.2)}$ of Amicon PM10 filtrate of PHA-activated leukocyte culture supernate, revealing two separate peaks of biological activity (big and little OAF). The column marker for 13,700 daltons is ribonuclease A. The PM10 filtrate was concentrated on a UM2 membrane before application to the column.

was another peak of bone-resorbing activity which eluted from the Sephadex G-50 column with the salt volume and in the same position as the marker $\left[{ }^{3} \mathrm{H}\right]$ proline (Fig. 2). We have called this peak of boneresorbing activity little OAF. When the bone-resorbing activity which eluted from the Sephadex G-50 column with $\left[{ }^{3} \mathrm{H}\right]$ proline was rechromatographed, most of the biological activity eluted from the column in approximately the same position, although some of the activity was found in the void volume of the column (Fig. 3).

Dissociation of big to little OAF. Big OAF, which was obtained from Sephadex G-50 column chromatography or by diafiltration of an Amicon PM10 retentate, was first equilibrated separately with $1 \mathrm{M} \mathrm{NaCl}$ or $2 \mathrm{M}$ urea. Under these circumstances, the biological activity which was previously retained by an Amicon PM10 membrane now appeared in the Amicon PM10 filtrate (Table I). The biological activity which passed

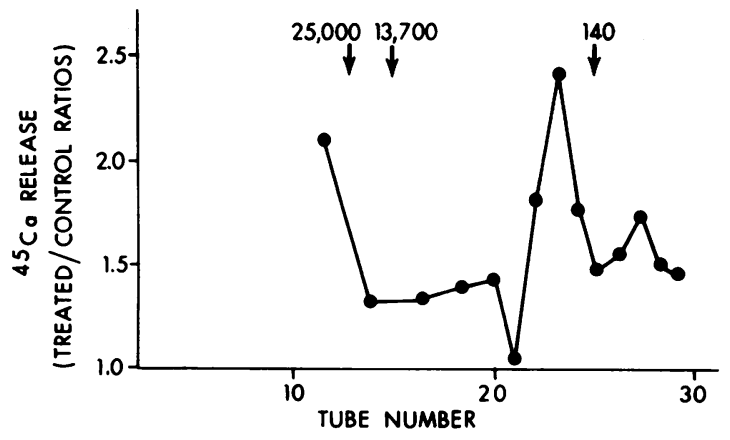

FIGURE 3 Sephadex G-50 chromatogram in phosphatebuffered saline (ionic strength $150 \mathrm{mM}, \mathrm{pH} \mathrm{7.2)} \mathrm{of} \mathrm{little}$ OAF obtained from chromatogram represented in Fig. 2. The little OAF was concentrated on a UM2 membrane before application to the column. through the Amicon PM10 membrane after equilibration with $1 \mathrm{M} \mathrm{NaCl}$ was concentrated on a UM2 membrane (molecular weight cutoff 1,000 daltons). This UM2 retentate was then chromatographed on a Sephadex G-50 column and on a Bio-Gel P6 column. The bone-resorbing activity eluted from the Sephadex column in the same position as little OAF obtained by Amicon ultrafiltration (Fig. 4). The same material on a Bio-Gel P6 column eluted between the molecular weight markers calcitonin (3,500 daltons) and vitamin $\mathrm{B}_{12}$ (1,330 daltons) (Fig. 5).

Little OAF self-association. When the biological activity which eluted from Sephadex G-50 columns in the little OAF area was equilibrated by dialysis in buffers of low ionic strength (Tris- $\mathrm{HCl} 50 \mathrm{mM}$ ) and rechromatographed on a Sephadex G-50 column in Tris- $\mathrm{HCl}$ buffer, the biological activity eluted from the column in two peaks, corresponding approximately to the previously observed peaks for big and little OAF (Fig. 6). When the biological activity which had passed through an Amicon PM10 membrane after equilibration in $1 \mathrm{M} \mathrm{NaCl}$ was reequilibrated in Tris- $\mathrm{HCl} 10$ $\mathrm{mM}$, the biological activity was retained by the Amicon membrane (Fig. 7). These data confirm that under conditions of low ionic strength, little OAF self-associates back to big OAF.

Dialysis of little OAF. Little OAF obtained by Amicon ultrafiltration after dissociation with $1 \mathrm{M}$ $\mathrm{NaCl}$ was dialyzed using boiled Spectrapor no. 3 dialysis tubing (assigned molecular weight cutoff 3,500 daltons). All of the biological activity was retained inside the dialysis membrane (Table II). After dialysis, there was a marked increase in biological

TABLE I

Change in the Ultrafiltration Characteristics of OAF after Equilibration in $1 \mathrm{M} \mathrm{NaCl}$ or $2 \mathrm{M}$ Urea

\begin{tabular}{lc}
\hline \multicolumn{1}{c}{ Sample } & $\begin{array}{c}\text { s5Ca release } \\
\text { (treated/control } \\
\text { ratios)* }\end{array}$ \\
\hline Original crude OAF & $1.71 \pm 0.31 \ddagger$ \\
Crude OAF and 1 M NaCl-PM10 retentate & $1.92 \pm 0.51 \ddagger$ \\
Crude OAF and 1 M NaCl-PM10 filtrate & $2.18 \pm 0.32 \ddagger$ \\
Crude OAF and 2 M urea-PM10 retentate & $1.47 \pm 0.08 \ddagger$ \\
Crude OAF and 2 M urea-PM10 filtrate & $2.53 \pm 0.28 \ddagger$
\end{tabular}

Crude OAF was prepared by concentrations of a crude supernate from a PHA-activated leukocyte culture across an Amicon PM10 membrane. OAF was equilibrated in $1 \mathrm{M}$ $\mathrm{NaCl}$ or $2 \mathrm{M}$ urea and then diafiltered with $10 \mathrm{vol}$ of phosphate-buffered saline, ionic strength $150 \mathrm{mM}$, pH 7.2 across an Amicon PM10 membrane. The diafiltrate was concentrated back to the original volume of crude OAF with an Amicon UM2 membrane (nominal mol wt cutoff, 1,000 daltons). All of the assays were performed after 10-fold dilution of the sample in fresh culture medium.

* Values are means and SE for four bone cultures.

f Significantly greater than $1.0, P<0.05$. 


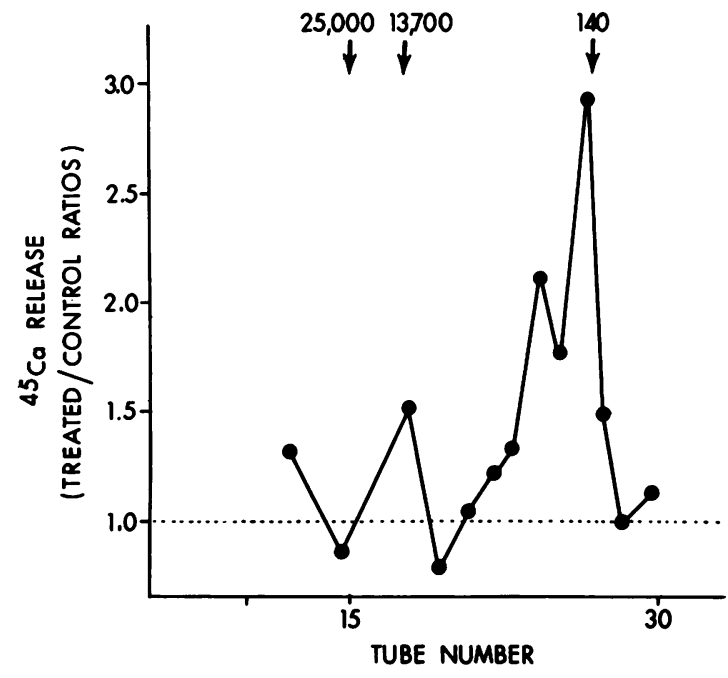

FIGURE 4 Sephadex G-50 gel filtration of big OAF (obtained from chromatogram represented in Fig. 1) after equilibration in $1 \mathrm{M} \mathrm{NaCl}$, diafiltration across an Amicon PM10 membrane with $10 \mathrm{vol}$ of phosphate-buffered saline, (ionic strength $150 \mathrm{mM}, \mathrm{pH} 7.2$ ) and concentration of PM10 filtrate on Amicon UM2 membrane. The Sephadex G-50 column was equilibrated in phosphate-buffered saline, ionic strength $150 \mathrm{mM}, \mathrm{pH} 7.2$.

activity in the most concentrated sample. The inhibitory effect in the nondialyzed sample may be due to the presence of a dialyzable nonspecific toxin to the bone cultures or a dialyzable inhibitor of little OAF.

Extraction in ethyl acetate. The biological activity, which eluted from Sephadex G-50 columns and BioGel P6 columns in the Little OAF area or which was prepared by salt dissociation and Amicon ultrafiltration, was extracted in ethyl acetate after acidification of the medium to pH 3.5 (Table III). Under these circumstances, all the biological activity appeared in the organic phase. When the $\mathrm{pH}$ of the medium was

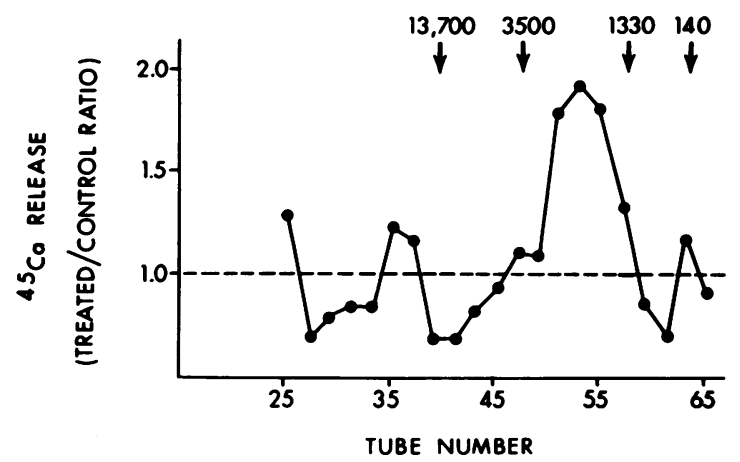

FIGURE 5 Bio-Gel P6 gel filtration of little OAF prepared by dissociation of big OAF with $1 \mathrm{M} \mathrm{NaCl}$ as in Fig. 4 . The column was equilibrated in phsophate-buffered saline, ionic strength $150 \mathrm{mM}, \mathrm{pH}$ 7.2. The column markers are ribonuclease $\mathrm{A}$ (13,700 daltons), calcitonin (3,500 daltons), and vitamin $B_{12}$ (1,330 daltons).

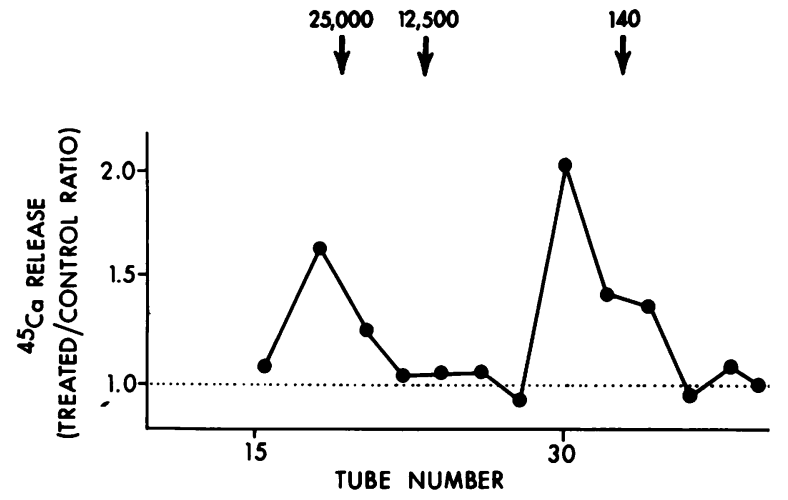

FIGURE 6 Sephadex G-50 chromatography of little OAF (obtained from chromatogram represented in Fig. 4) after equilibration with Tris-HCl $50 \mathrm{mM}$. Biological activity was eluted in Tris- $\mathrm{HCl} 50 \mathrm{mM}$ buffer, $\mathrm{pH}$ 7.6.

adjusted to 8.4 before extraction, the biological activity remained in the aqueous phase. In another experiment, the biological activity remained in the aqueous phase when extracted with ethyl acetate at $\mathrm{pH} 7.5$, but then was extracted into the organic phase after acidification of the aqueous phase to pH 3.5 (data not shown). Little OAF which was extracted in ethyl acetate at pH 3.5 was chromatographed on a Sephadex G-50 column in Tris- $\mathrm{HCl} 50 \mathrm{mM}$. All of the biological activity eluted from this column in the big OAF area (Fig. 8).

Effect of enzyme digestion. Big and little OAF were incubated with the proteolytic enzymes trypsin

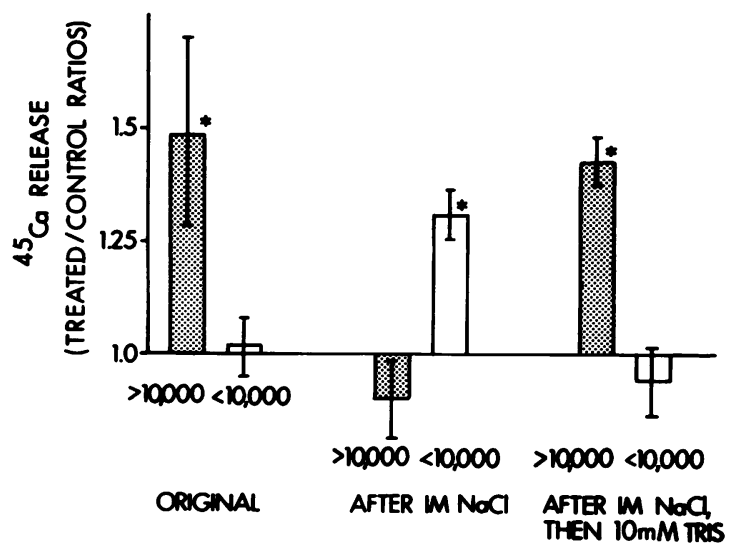

FIgURE 7 Dissociation and reaggregation of OAF across an Amicon PM10 membrane (nominal mol wt cutoff 10,000 daltons). An OAF containing leukocyte culture supernate was equilibrated with Tris- $\mathrm{HCl} 50 \mathrm{mM}$. All of the biological activity was retained by a PM10 membrane after diafiltration with $10 \mathrm{vol}$ of this buffer (left-hand pair of assays). When the OAF was equilibrated with $1 \mathrm{M} \mathrm{NaCl}$, all of the activity passed through the membrane on diafiltration with 10 vol of phosphate-buffered saline, ionic strength $150 \mathrm{mM}$, (center-pair of assays). When this little OAF was equilibrated with Tris-HCl $10 \mathrm{mM}$, the activity was retained by PM10 membrane after diafiltration with $10 \mathrm{vol}$ of this same buffer (right-hand pair of assays).

Big and Little Osteoclast Activating Factor 
TABLE II

Dialysis of Little OAF

\begin{tabular}{|c|c|c|}
\hline \multirow[b]{2}{*}{ Sample concentration } & \multicolumn{2}{|c|}{${ }^{45} \mathrm{Ca}$ release (treated/control ratios) $)^{*}$} \\
\hline & Original & After dialysis \\
\hline $1 / 20$ & $0.43 \pm 0.01$ & $1.46 \pm 0.16$ \\
\hline $1 / 80$ & $1.59 \pm 0.13 \ddagger$ & $1.75 \pm 0.22$ \\
\hline $1 / 320$ & $1.48 \pm 0.15 \ddagger$ & $1.29 \pm 0.11$ \\
\hline
\end{tabular}

Little OAF was prepared by equilibration of big OAF in $1 \mathrm{M} \mathrm{NaCl}$ and diafiltration across an Amicon PM10 membrane with 10 vol of phosphate-buffered saline, ionic strength $150 \mathrm{mM}$. Little OAF was dialyzed against $100 \mathrm{vol}$ of BGJ medium for $24 \mathrm{~h}$ using Spectrapor no. 3 dialysis tubing (nominal mol wt cutoff about 3,500 daltons). After dialysis, the sample was diluted $20-, 80-$, or 320 -fold with fresh BGJ medium before assay.

* Values are means and SE for four bone cultures.

† Significantly greater than $1.0, P<0.05$.

and papain. There was a decrease in the biological activity of little OAF, but not of big OAF after incubation with either enzyme at high concentration (Table IV). Failure of proteolytic enzymes to inactivate big OAF may have been due to the presence of contaminating proteins in the sample or to a protected conformation of big OAF.

TABLE III

Extraction of OAF in Ethyl Acetate

\begin{tabular}{|c|c|c|c|}
\hline \multirow[b]{2}{*}{ Sample } & \multicolumn{3}{|c|}{ Percent release of ${ }^{45} \mathrm{Ca}^{*}$} \\
\hline & $\begin{array}{c}\text { Not } \\
\text { extracted }\end{array}$ & $\begin{array}{l}\text { Extracted with } \\
\text { ethyl acetate } \\
\text { pH } 3.5\end{array}$ & $\begin{array}{c}\text { Extracted with } \\
\text { ethyl acetate } \\
\text { pH 8.4 }\end{array}$ \\
\hline $\begin{array}{l}\text { Little OAF prepared } \\
\text { by gel filtration } \\
(\mathrm{G}-50) \downarrow\end{array}$ & $36 \pm 2 \ddagger$ & $37 \pm 2 \ddagger \ddagger$ & $21 \pm 2$ \\
\hline $\begin{array}{l}\text { Little OAF prepared } \\
\text { by salt dissocia- } \\
\text { tion } \S\end{array}$ & $35 \pm 11$ ft & $54 \pm 8 \rrbracket \ddagger$ & $17 \pm 3$ \\
\hline Big OAF" & $51 \pm 6 \ddagger \ddagger$ & $21 \pm 1$ & \\
\hline $\begin{array}{l}\text { Prostaglandin } E_{2}, \mathbb{1} \\
\qquad 10 \mu \mathrm{M}\end{array}$ & $43 \pm 5 \ddagger$ & $64 \pm 6 \ddagger$ & \\
\hline $\begin{array}{c}1,25(\mathrm{OH})_{2} \mathrm{D}_{3},{ }^{* *} \\
10 \mu \mathrm{g} / \mathrm{ml}\end{array}$ & $58 \pm 7 \ddagger$ & $63 \pm 7 \ddagger$ & \\
\hline Control medium & $21 \pm 1$ & $19 \pm 1$ & $19 \pm 1$ \\
\hline
\end{tabular}

* Values are means and SE for four bone cultures.

† As in Fig. 2.

$\$$ As in Table I.

"Prepared by gel filtration, as in Fig. 1.

If Prostaglandin $\mathrm{E}_{2}$ was provided by the Upjohn Co., Kalamazoo, Mich.

** 1,25-dihydroxyvitamin $\mathrm{D}_{3}$ was provided by Roche Diagnostics Div., Hoffmann-LaRoche, Inc., Nutley, N. J.

$\$$ Significantly greater than corresponding control, $P<0.05$.
Assay for prostaglandin-like activity. Purified little OAF after ethyl acetate extraction (Table V) was assayed for prostaglandin-like activity at a concentration which had maximal bone resorbing activity. The concentration of prostaglandin-like activity by the rat-fundus assay found in the sample was less than the equivalent of $0.1 \mathrm{nM}$ of prostaglandins E. Prostaglandin $E_{2}$ is the most potent known bone-resorbing prostaglandin (11), but concentrations of $1-10 \mu \mathrm{M}$ are required to produce maximal bone resorption. Thus, the biological activity in little OAF samples cannot be ascribed to known prostaglandins.

Purification steps. Table V shows a summary of the stepwise purification of OAF achieved by ultrafiltration, salt dissociation, column chromatography, and extraction in ethyl acetate. The final sample was over 6,000 -fold purified compared with the original leukocyte supernate and contained a protein concentration of $80 \mathrm{ng} / \mathrm{ml}$ as measured by the method of Lowry et al. (12).

\section{DISCUSSION}

The present study shows that the bone-resorbing activity produced by PHA-activated leukocyte culture supernates which we have termed OAF is heterogeneous. There are two distinct peaks of bone resorbing activity which can be distinguished by gel filtration chromatography. We have called the larger peak big OAF and the smaller peak little OAF. Both of these peaks have similar biological effects to those previously described for OAF (5). After equilibration of big OAF with $1 \mathrm{M} \mathrm{NaCl}$ or $2 \mathrm{M}$ urea, the biological activity can be eluted from Sephadex G-50 columns in the same fraction as little OAF, thus suggesting that little OAF is either a subunit of big OAF or is bound to a

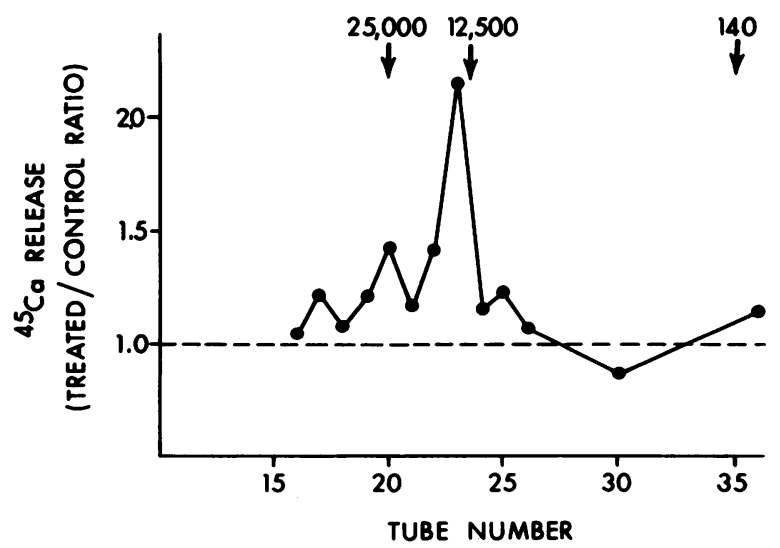

Figure 8 Sephadex G-50 gel filtration of little OAF extracted in ethyl acetate after acidification of the media to pH 3.5. The organic phase was dried, and the residue was dissolved in Tris- $\mathrm{HCl}$ buffer, ionic strength $50 \mathrm{mM}, \mathrm{pH}$ 7.6. The column was equilibrated in the same buffer. 
TABLE IV

Effect of Enzyme Digestion on Big OAF and Little OAF

\begin{tabular}{lccl}
\hline \multirow{2}{*}{ Enzyme digestion } & \multicolumn{3}{c}{ Percent release of ${ }^{45} \mathrm{Ca}^{*}$} \\
\cline { 2 - 4 } & Control medium & Big OAF & Little OAF \\
\hline None & $19 \pm 1$ & $42 \pm 4 \ddagger$ & $30 \pm 2 \ddagger$ \\
Trypsin, $400 \mu \mathrm{g} / \mathrm{ml}$ & $16 \pm 1$ & $42 \pm 6 \ddagger$ & $21 \pm 1 \ddagger \S$ \\
Papain, $240 \mu \mathrm{g} / \mathrm{ml}$ & $17 \pm 1$ & $41 \pm 4 \ddagger$ & $20 \pm 1 \S$ \\
\hline
\end{tabular}

Big OAF was prepared by gel filtration as in Fig. 1. Little OAF was prepared by salt dissociation as in Table I. The samples were incubated with the enzymes for $1 \mathrm{~h}$ at $\mathrm{pH} 7.4$ at $37^{\circ} \mathrm{C}$. After enzyme incubation the samples were diluted with fresh BGJ medium containing $4 \mathrm{mg} / \mathrm{ml}$ bovine serum albumin.

* Values are means \pm SEM for four bone cultures.

\$ Significantly different from control $(P<0.05)$.

$\$$ Significantly different from response without enzyme $(P<0.05)$.

carrier protein. When little OAF was equilibrated in buffers favoring self-association and chromatographed again on Sephadex G-50 columns, the biological activity eluted from these columns in the big OAF area. While this could indicate that big OAF is a polymer of little OAF, it is not certain that the reaggregated activity and the original big OAF are identical.

It is not possible to make a reliable estimate of the size of little OAF from these data. It is likely that little OAF is larger than its elution with proline on the Sephadex G-50 columns might indicate. When Little OAF was chromatographed on a Bio-Gel P6 column, the biological activity eluted between the molecular weight markers calcitonin (3,500 daltons) and vitamin $B_{12}$ (1,330 daltons). Moreover, the activity was not lost after dialysis using Spectrapor No. 3 dialysis tubing (assigned molecular weight cutoff 3,500 daltons). Little OAF was retained after diafiltration with an Amicon UM2 membrane which has an assigned molecular weight cutoff of 1,000 daltons. Late elution of little OAF on Sephadex G-50 columns may be due to binding of little OAF to the Sephadex, with eventual elution due to dissociation by the amino acids in the culture medium. The biological activity was widely dispersed when little OAF was chromatographed on a Sephadex G-25 column, ${ }^{2}$ and some activity eluted after a proline marker. This also suggests that little OAF binds to Sephadex.

Both big and little OAF are clearly separable from other soluble mediators of bone resorption such as PTH, active vitamin D metabolites, and prostaglandins. Prostaglandins and active vitamin D metabolites have more shallow dose-response curves than OAF or PTH $(5,6)$ and are readily extractable in lipid solvents $(3)$. Moreover, radioimmunoassays for PTH and prosta-

\footnotetext{
${ }^{2}$ Mundy and Raisz. Unpublished observations.
}

glandins of biologically active peaks eluting from Sephadex columns did not show sufficient concentrations of PTH or prostaglandins to account for the boneresorbing activity found (3). Like PTH, OAF probably depends on a peptide sequence for biological activity as little OAF was inactivated by proteolytic enzymes (Table IV). The impure preparations of big OAF used in these experiments were not activated by proteolytic enzymes, possibly due to the presence of contaminating proteins in the sample. Using different purification methods, we found big OAF to be inactivated by these enzymes previously (3).

Although little OAF, but not big OAF, could be extracted into ethyl acetate after acidification, it is unlikely that little OAF is a prostaglandin. Bioassay of active little OAF preparations for prostaglandin-like activity indicated that there was not enough prostaglandin-like activity present to account for the boneresorbing activity. Moreover, the dissociation/selfassociation properties of $\mathrm{OAF}$, the retention of biological activity after dialysis, and the loss of biological activity after incubation with proteolytic enzymes all suggest that the bone-resorbing activity of little OAF preparations is not due to known prostaglandins $\mathrm{o}_{i}$ prostaglandin-like compounds.

It is likely that little OAF escaped detection initially because it is not present in crude leukocyte supernates in concentrations as great as big OAF, and because it has a steep biphasic dose-response curve with significant inhibition of activity at concentrations only two- to fourfold greater than those giving maximal activity. Thus, unless multiple dilutions are bioassayed, bone-resorbing activity may be missed in samples which contain potent biological activity. The reason for decreased activity of little OAF prep-

TABLE V

Summary of OAF Purification

\begin{tabular}{|c|c|c|c|}
\hline Sample & $\begin{array}{c}\text { Protein } \\
\text { concentration* }\end{array}$ & $\begin{array}{l}\text { Purifica- } \\
\text { tion } \$\end{array}$ & Yield§ \\
\hline & $\mu g / m l$ & & $\%$ \\
\hline Crude leukocyte supernate & 500 & 1 & 100 \\
\hline PM10 concentrate & 125 & 4 & 40 \\
\hline $\begin{array}{l}\text { PM } 10 \text { retentate after } \\
\text { diafiltration (Table } \mathrm{I} \text { ) }\end{array}$ & 31 & 15 & 160 \\
\hline $\begin{array}{l}\text { PM } 10 \text { filtrate after } \mathrm{NaCl} \\
\text { equilibration (Table I) }\end{array}$ & 6 & 90 & 40 \\
\hline P6 (Fig. 5) & 0.6 & 855 & 3.5 \\
\hline $\begin{array}{l}\text { Ethyl acetate extraction } \\
\text { of } P 6 \text { eluant }\end{array}$ & 0.08 & 6,665 & 3.5 \\
\hline
\end{tabular}

* The minimal protein concentration in the sample which contains maximal biological activity ( $\mathrm{T} / \mathrm{C}$ ratio 2.0 ).

† Calculated relative to original crude leukocyte supernate.

$\S$ Calculated as bone-resorbing doses in sample as percent of original.

Big and Little Osteoclast Activating Factor 
arations at high concentrations is uncertain. The inhibitory effect can be removed by dialysis (Table II). It is possible that little OAF preparations contain a natural inhibitor or that the hypertonic solutions obtained after salt dissociation are responsible for the inhibition of bone resorption. Little OAF has been difficult to purify further because the biological activity is not retained after more than a few weeks at $-20^{\circ} \mathrm{C}$. Nevertheless, the methods used have resulted in a high degree of purification, with over a 6,000 -fold increase in specific activity of the most purified sample relative to the original starting material.

The relationship of OAF to other lymphokines is unknown at present. Human macrophage migration inhibition factor and chemotactic factor are probably larger than OAF and elute from Sephadex G-100 columns around the chymotrypsinogen marker $(25,000$ daltons) (13). Current evidence suggests that human lymphotoxin is also considerably larger than OAF (14). OAF is not the only lymphokine which shows more than one peak of biological activity on Sephadex chromatography. There is some evidence that chemotactic factor is heterogeneous and may undergo reaggregation (14). We have not assayed OAF preparations for chemotactic activity, but the reported behavior of chemotactic factor on Sephadex columns does not correspond with that of OAF.

It is possible that $\mathrm{OAF}$ is an important mediator of bone resorption both in health and disease. We have found that cultured neoplastic cells in patients with myeloma and a number of other B-cell lymphoproliferative disorders produce a bone-resorbing factor with similar chemical and biological characteristics to OAF $(6,7)$. Positive identification of these factors and their differentiation from OAF awaits more specific assays and further purification. OAF could be produced either by the neoplastic cells or by normal leukocytes in the cellular immune response stimulated by tumors. OAF is also a potential mediator of the bone resorption which occurs adjacent to areas of chronic inflammatory cell infiltration in diseases such as rheumatoid arthritis, periodontal disease and cholesteatoma (15). Krane et al. (16) have found that cultured synovial cells from patients with rheumatoid arthritis secrete a bone resorbing factor smaller than big OAF but distinct from prostaglandins which are also produced by synovial cell cultures (17).

\section{ACKNOWLEDGMENTS}

The authors thank Dr. Milan Uskokovic of HoffmannLaRoche, Inc., Nutley, N. J. for his kindly having provided 1,25-dihydroxyvitamin $D_{3}$ for these experiments.

This work was supported by research grant DT-49 from the American Cancer Society and grant AM-18063 from the National Institutes of Health.

\section{REFERENCES}

1. Biggers, J. D., R. B. L. Gwatkin, and S. Heyner. 1961. Growth of embryonic avian and mammalian tibiae on relatively simple chemically defined medium. Exp. Cell Res. 25: 41-58.

2. Horton, J. E., L. G. Raisz, H. A. Simmons, J. J. Oppenheim, and S. E. Mergenhagen. 1972. Bone resorbing activity in supernatant fluid from cultured human peripheral blood leukocytes. Science (Wash. D. C.). 177: 793-795.

3. Luben, R. A., G. R. Mundy, C. L. Trummel, and L. G. Raisz. 1974. Partial purification of osteoclast-activating factor from phytohemagluttinin-stimulated human leukocytes. J. Clin. Invest. 53: 1473-1480.

4. Trummel, C. L., G. R. Mundy, and L. G. Raisz. 1975. Release of osteoclast activating factor by normal peripheral blood leukocytes. J. Lab. Clin. Med. 85: 1001-1007.

5. Raisz, L. G., R. A. Luben, G. R. Mundy, J. W. Dietrich, J. E. Horton, and C. L. Trummel. 1975. Effect of osteoclast activating factor from human leukocytes on bone metabolism. J. Clin. Invest. 56: 408-413.

6. Mundy, G. R., R. A. Luben, L. G. Raisz, J. J. Oppenheim, and D. N. Buell. 1974. Bone-resorbing activity in supernatants from lymphoid cell lines. N. Engl. J. Med. 290: 867-871.

7. Mundy, G. R., L. G. Raisz, R. A. Cooper, G. P. Schechter, and S. E. Salmon. 1974. Evidence for the secretion of an osteoclast stimulating factor in myeloma. N. Engl. J. Med. 291: 1041-1046.

8. Raisz, L. G., and I. Niemann. 1969. Effect of phosphate, calcium and magnesium on bone resorption and hormonal responses in tissue culture. Endocrinology. 85: 446-452.

9. Raisz, L. G. 1965. Bone resorption in tissue culture. Factors influencing the response to parathyroid hormone. J. Clin. Invest. 44: 103-116.

10. Vane, J. R. 1957. A sensitive method for the assay of 5hydroxy-tryptamine. Br. J. Pharmacol. Chemother. 12: 344-349.

11. Dietrich, J. W., and L. G. Raisz. 1975. Prostaglandin in calcium and bone metabolism. Clin. Orthop. Relat. Res. 111: 228-237.

12. Lowry, L. H., N. J. Rosebrough, A. L. Farr, and R. J. Randall. 1951. Protein measurement with the Folin phenol reagent. J. Biol. Chem. 193: 265-275.

13. Rocklin, R. E., H. G. Remold, and J. R. David. 1972. Characterization of human migration inhibitory factor (MIF) from antigen-stimulated lymphocytes. Cell. Immunol. 5: 436-445.

14. David, J. R., and R. R. David. 1972. Cellular hypersensitivity and immunity. Inhibition of macrophage migration and the lymphocyte mediators. Prog. Allergy. 16: $300-449$.

15. Raisz, L. G., C. L. Trummel, G. R. Mundy, and R. A. Luben. 1975. Immunologic factors influencing bone resorption. Role of osteoclast activating factor from human lymphocytes and complement mediated prostaglandin synthesis. In Calcium-Regulating Hormones. R. V. Talmage, M. Owen, and J. A. Parsons, editors. Excerpta Medica, Amsterdam. 149-153.

16. Krane, S. M., R. D. Emkey, and L. Ferzoco. 1971. The enhancement by rheumatoid synovial culture media of ${ }^{45} \mathrm{Ca}$ release from prelabeled fetal bones. Arthritis Rheum. 14: 396-397. (Abstr.)

17. Robinson, D. R., A. H. Tashjian, Jr., and L. Levine. 1975. Prostaglandin-stimulated bone resorption in rheumatoid synovia. A possible mechanism for bone destruction rheumatoid arthritis. J. Clin. Invest. 56: 1181-1188. 